UDC 101:37

M. I. Zakharina, Assistant

\title{
THE EDUCATION OF FREE INDIVIDUAL AS THE MAIN VALUE OF THE WELFARE OF THE SOCIAL STATE IN THE SCIENTIFIC HERITAGE OF V. ZENKOVSKY
}

\begin{abstract}
V. Zenkovsky (1881-1962) was born in. Proskuriv (now Khmelnitsky) in a family of teachers. He studied and worked for some time in Kiev. And in 1918 five months served as minister of culture and religion in the government of Hetman P. P. Skoropadskoho and member of the Council of Ministers of the Ukrainian state. Where he is trying to reform the management Sv. Synodu of Russian Empire in Ukraine and directed its efforts at developing national culture as a necessary factor for the development of the Ukrainian state. After the revolution, he had to emigrate abroad.

Great attention Zenkovsky concentrated to national education for every child, because "it has to attract people to the history of her country, to develop awareness of its duty to their homeland." He considered the question of national education in his publication "The national question in the world of Christianity." His interpretation of love for the Motherland sounds like a poem. Perhaps this is because he had to leave it after the events related to the revolution in Russia. In addition, in this regard, he had to live and work abroad until his death. "The peoples have their own strange destiny - to grow a given historical existence, others are not given - they are just on the border of historical existence. It is a source of painful experiences for a range of people - against them usually discarded right to real, national existence. Such a fate like Ukrainian."

The article analyzes the views of the philosopher $V$. Zenkovsky on the role of education in the formation of a free personality and the phenomenon of a free person. And also the spiritual and educational sense of freedom is considered in the context of building a social society.

Also, an attempt to offer a holistic understanding of the phenomenon free person as defining the basics of human life on the example of the works of famous teacher and public figure V. Zenkovsky that will help in terms of reformation processes in the national education to understand the meaning of social education rights.
\end{abstract}

Keywords: Zenkovsky; spirituality; freedom; free personality; national education.

М. І. Захаріна, асистент

\section{ВИХОВАННЯ ВІЛЬНОЇ ОСОБИСТОСТІ ЯК ГОЛОВНОЇ ЦІННОСТІ СОЦІАЛЬНОЇ ДЕРЖАВИ У НАУКОВІЙ СПАДЩИНІ В. ЗЕНЬКОВСЬКОГО}

Анотація. У статті аналізуються погляди фрілософа В. Зеньковського на роль виховання при фрормуванні вільної особистості і френомена вільної людини. А також розглядається духовно-виховний сенс свободи в контексті побудови соціальної держави.

Ключові слова: Зеньковський; духовність; свобода; вільна особистість; національне виховання.

М. И. Захарина, ассистент

\section{ВОСПИТАНИЕ СВОБОДНОЙ ЛИЧНОСТИ КАК ГЛАВНОЙ ЦЕННОСТИ СОЦИАЛЬНОГО ГОСУДАРСТВА В НАУЧНОМ НАСЛЕДИИ В. ЗЕНЬКОВСКОГО}

Аннотация. В статье анализируются взгляды философра В. Зеньковского на роль воспитания при фрормировании свободной личности и феномена свободного человека. $A$ также рассматривается духовно-воспитательный смысл свободы в контексте построения социального общества.

Ключевые слова: Зеньковский; духовность; свобода; свободная личность; национальное воспитание.

Actual scientific researches and issues analysis. In the National Doctrine of Education it is pointed that education is the foundation for the development of the personality, society, nation and 
State guarantee Ukraine's future. "It is decisive factor of political, social, economic, cultural and ientific of society. Education plays and builds intellectual, spiritual and economic potential of society" [1]. So, education is a prerequisite for human development, training a new generation capable of a social and legal state, as part of the European community.

Modern Ukrainian Viktor Andrushchenko philosopher in his book "Reflections on education: articles, essays, interviews," said : "Education now appears not only as the field of training and education of children and youth, vocational training or retraining, as the main institutional mechanism for organizing initial and future life creation - man preparing for life in the broadest sense, but also as one of the main institutions of the implementation of national security, the vitality of the people, culture and state, strengthening their authority to international and stage. Last updates the social role of education in the state strategy, which in turn changes its place and functional load in the context of the general concept of sustainable human development". [1]

Actual scientific researches and issues analysis. Such scholars as V. Andrushchenko, V. Beh, N. Hendina, B. Hershunskyy, Dzh. Dyui, D. Dzvinchuk, V. Zhuravsky, B. Zablocki, V. Kremen, M. Kviyek, riveting C. Korsak, B. Meyer, C. Ognevyuk, A. Prokopenko, G. Stasiuk and others studied the formation of the welfare state means of education. In our opinion, some provisions of free personality education as the main values of the welfare state in the scientific heritage of Vasily Zenkovsky are interesting.

The research objective. The purpose of this article is to examine the views of philosopher and scientist Vasily Zenkovsky on the role of education in the development of free personality in the sociale state.

The statement of basic materials. Vasil Vasylovych Zenkovsky is known as domestic philosopher, theologian, teacher, psychologist. In the spectrum of his philosophical and educational heritage, the special attention is focused on the development of ethical and anthropological perspective, which is analyzed in the context of Christian religious consciousness of believers. The prominent place in V. V. Zenkovsky's works takes the building of theoretical model of the human's holistic world. And it is quite natural, because the person who seamlessly combines different aspects of life, seeks to a holistic, harmonious, full of high spiritual meaning outlook.

The phenomenon of philosophical and educational heritage of Zenkovsky integrates distinctive worldview, special vision of spiritual principles of human development, the importance of education for the development of the personality, education of the personality in line with freedom. His deep patriotism and devotion to the ideals of religion, the priority of human values, deep knowledge of pedagogy, psychology, philosophy, economics are still relevant to the present for today's youth.

Uninvestigated parts of general matters defining. Zenkovsky's educational views did not lose their relevance in the current development of education. National education in the spirit of patriotism, the desire for constant renewal of education, priority of education in the development of personality, the creationof the integrated system of knowledge are of particular importance in the present conditions of our country, the development of national schools and national education in Ukraine.

Crucial sense to the education system is dependent on the political commitment of each state, because each state system seeks to prepare professionally prepared youth, particularly personnel experts for science education. And every polity makes demands on the education system in order to put into practice the national policy.

Zenkovsky thought that education must be responding time, it must meet the needs of living and prepare people to a new composition with other skills and other concepts. This deepening of education is that schools (and other organs of education, of course) should take over the task of social education and should prepare not only educated people, not only individual employees, but also the capable citizens of social work, inspired by the ideals of solidarity. Thus, the necessary internal reform school affairs, deepen and approach to life. Exactly school should be a body of social education, "to be a carrier of higher ideals of community and a true instrument of social progress."

Zenkovsky gave the great importance to the national education, which, in his opinion, fills the soul with national content through language and literature and makes conscious and able to be useful citizens of the country ,must attach to the history of his country, to develop a sense of duty to the motherland.

Even Ushinsky K. D. in 1867 drew attention to a new understanding of the purpose of education. In his work "Man, as a matter of education. Experience of teaching anthropology" determined that before 
talking about education rights, we should answer the question, what is the nature of man, and what should be the man. The task of education is to develop the moral side of the child, and the human's moral ideal should always be on the first side - the ideal for which the God revealed Christian doctrine should serve as the basis. The impact of morality - said Ushinsky - is the main task of education is much more important than the development of the mind in general, filling head with the knowledge, explaining each person of his personal interest " .

Considering the theme of formation and education of the individual, Zenkovsky paid much attention to childhood, believing that in the childhood a person is opened to senseconsciousness and sensecreation, and that's why the child's personality is complete. Children's spiritual is over and dominant under practical. This spiritual senses, originality is the key to his participation in an integrated world.

One of the characteristics of integrity, harmony of personality is its moral determinants. Of course, the social environment influences the formation and outlook and lifestyle, and character behavior. But personal guidance are also determined by its internal, spiritual world. In this regard, a person characterized by strength of mind, will, creativity. The personality rises above its natural, biological basis and in a sense it overcomes, coming into the world beyond physical entities.

Thus, the spiritual in man is a value and a moral principle, which should lead to inner balance, selfrenewal of the soul, assertiveness rights in the social world, and eventually to humanregularity outlook.

V. V. Zenkovskyy compares spirituality with the creative force in a man, which permeates all human's life (and soul and body) and defines a new "quality" of life. In spiritual inn organic hierarchy in man integrity is formed: "... and if it is not expressed in a real human being, it means some connectivity spirituality in man, some significant" disorder spirit, as would later be called the same as sin on the religious language [6, p. 45].

From the standpoint of Christian anthropology as the theoretical and methodological framework concept of V. V. Zenkovskyi, the most important meaning of education of the individual sees in the ascent to the spiritual foundation of the individual, and in this sense everything in a person is recognized through the development of body, intellect, social, religious, moral, aesthetic spheres of individual to spirituality. Therefore, the leading areas of education (physical, sexual, social, moral, religious, aesthetic, intellectual) serve as elements of a personality of spiritual education using empirical effects on the sector as a sphere of objectification spiritual. Within each of these areas allocated by reference to the means of education, as part of moral education can be identified as the most significant in terms of V. V. Zenkovskui: prayer, worship, confession, theological books, etc., within aesthetic education, sculpting, painting , dancing, story, literature, etc., as part of physical education - sports, gymnastics, hiking, wellness powers of nature, etc.

Irina Predborska indicates that all of his educational model of education was humanoriental and all his philosophical and pedagogical concept was aimed at finding ways to nurture individuality.

He attracted the attention of teachers, that it is necessary to develop in a child in the process of education, it is - the liberation and awakening the child therein initiatives, to develope in it activity and initiative and, finally, the deepening and development of the social forces of his personality. These three ideas are inextricably linked to each other, "the release of the child provides space activity and the development of social forces - and vice versa development of social forces provides relief the child from the imposed regime and waking activity - and in in its turn for the wakening up the activity freedom of expression and social conditions of its application is required".

Expanding the theme of education of the individual Zenkovsky inseparably connects it with the theme of freedom. In his book "Problems of education in the light of Christian anthropology," he calls the principle of human's freedom and the biggest mystery of the central mystery of man. Here he examines the theme of the child's soul, which is closely related to the theme of freedom. But he also criticizes the Tolstoy's topic of free education, calling it as an educational anarchism.

His attitude to freedom deeply goes through life and opened: "Freedom shines human soul, not as a reality, not as given strength, but as an opportunity, as a problem - and just from the idea of freedom is the beginning of the liberation of man from the power nature of their past, their habits and preferences. Freedom is given and not given" [4, p. 13].

Philosopher argued that human's freedom is not given, but puted and a person should reveal it through creativity. And this is going to happen in childhood. With this statement topic of raising a child, 
is related, which he called "ascent to freedom." And the task of education to help the child become free, to find freedom. He saw no point in raising outside of liberty - "it turns out freedom in training, the suppression of the individual and humiliation it." But then there is another question - if you give children a choice, will they go to the evil side. It is very difficult for children to resist the temptation.

As a religious teacher, Zenkovsky linked freedom category to the category of "evil" in man, in choosing whether to be with God or without Him or even against Him. In the words of Blessed Augustine, original sin so deeply distorted human nature that it itself is not capable for good (non posse non peccare - "can't not to sin"). And the great gift of freedom - it is a terrible gift, which is the source of human tragedy and all its trials.

Probably that's why, V. V. Zenkovsky the considered the main task of education as to help the personality finding itself and learn to transform its "natural structure" aiming for good triune existence in human heredity, social, but above all - spirituality. The freedom of man is manifested in the fact that we can fulfill ourselves, to fill our life with the highest spiritual values, and perhaps unconsciously or consciously evade this exercise, assuming that builds his life completely autonomously and independently, and it is always an illusion. "We are free in that we take this tasks, understand it, let us implement it - but the existence of" inscribed " cross is the limit of our freedom, is the witness of our dependence on God who gives his cross to everyone" [5, p. 75].

Thus, each person is free in his choice: either accept his cross, to realize their integrity, to see the image of God in himself, to live a spiritual life, or take the other side, the side of evil. And philosopher devoted a separate article for this theme "The problem of evil in man", which proves the existence of "dark principle in the spiritual life of man", which was caused by original sin.

According to Zenkovsky the riddle of freedom is, that it's impossible to bring the child to the good forcibly, that freedom is not connected with good inside of us. After all, in fact, freedom gives the child the opportunity to act on his own and that education should lay the moral qualities that will direct his action for good.

Thus, personal liberty is qualitatively new feature that realizes itself through the assimilation of moral norms that are distinguished by freedom from tyranny. An obligatory condition for the process of self-realization, the main thrust of which is to identify the individual, acts inner freedom of the personality. The latter should be understood as being an autonomous personality, which provides resistance to external influences, maintaining itself as a whole, according to the laws of their domestic existence and development.

Zenkovsky in his works argued the impossibility of personality without learning Christian anthropology, considering the development of spiritual and human values parties necessary basis for its integrity as a proportion of the world natural and social. On this occasion he wrote: "Faith in the child's life, as the basis of" justification "of all education, properly interpreted only in the doctrine of man, which Christianity is developing."

In his article "Freedom and unity" Zenkovsky indicates the presence of two ways and two experience of freedom. "Natural "confronts " fertile "and faith in Christ, the observance of His commandments creates" right "to have a new man," the old man "is not converted and not enlightened, not only lives in us, but comes in very difficult and tense struggle with the "new" in us "[3, c. 3].

For Zenkovsky, as for the Christian philosopher ,the topic of interaction "Freedom in Christ" and genuine freedom that comes from the depths of human nature, is very important. He believes that natural grace and confront each other, but at the same time replacing each other, and these two ways is only one, albeit the most significant, the expression of this internal split.

Philosopher sures that "Freedom in Christ is wider, better than natural liberty, limited law of natural and social order..." [3, p. 5]. The presence of natural freedom we sometimes does not allow us to handle the riot and chaos of our heart and we begin to realize that although"everything is permitted", but "not all is profit."

For him, freedom in Christ is revealed in the person, but the person is the subject of freedom of the church as a whole. And an individual finds his freedom and realizes it not by itself, but only in the Church.

In the other article "Autonomy and theonomy" he continues the theme of freedom in Christ. "Our strength, our freedom, our work revealed only in communion with God, only through love, V. E. mysterious fusion with other people in the living unit, in other words, we find ourselves, we become not isolated from others, not immersed in ourselves, but in the Church and through the Church. The moral 
life in us (as all spiritual life in us) is a function of ecclesiastical in us; we find a source of strength not out of ourselves and not inside ourselves, but in God. Therefore, the whole system can be described in terms of theonomy" [2, p. 50].

Thus, there are three areas of Christian doctrine of freedom in the works of V. Zenkovskyi : First, is that the freedom which is given to man and he needs to reveal it through education. The Second, is the beginning of freedom in man ambiguous, in other words, the freedom does not exist "in itself", but the freedom in him is needed to be saved and educate. Third, it is recognition that a person can learn freedom, only in the church, that it is not separated and separately, and entering to the cathedral fertile life of the Church. Freedom is given and "secured" in its truth only in the Church, an individual can't capture all the gift of freedom.

Being abroad, Zenkovsky paid much attention to the topic of secularization of culture that led to the breakdown of the integrity of the individual. The increase in social struggles, the decline of spiritual life enhances the rapid development of individualism. All this leads to the suspension of creative life. To solve this problem one should revive orthodoxy integral culture which is exempt from nationalism. The scientist paid the particular attention to academic educational function of the school. In his report, "Background to the construction of a new school," he identified the following tasks for school: to fight deliberately and persistently with the championship of intellectualism in school; to make the transition from modern pedagogical voluntarism to emotionalism. It should be lead to the development of social movements in the child to his moral growth, strengthening religious movement and aesthetic creativity [5, p. 157].

Paying attention to the children of emigration, to their problems and mental condition, Zenkovsky led the socio-pedagogical study, which was conducted by V. Levytskyi in Czechoslovakia's schools, which examined the children's of emigration mental health. As the result the book "The Children of exile" was published. Analyzing the children's work on the topic "My memories from 1917» scientist found that a lot of children are in deep turmoil and breakdown in the child's heart that caused the events in Russia (1914-1919 years), the breaking with the usual life ,lost childhood, departure from the motherland. But in this regard, the children's a sense of family exacerbated, a bond with family, friends became stronger. This study helped to understand the child's psyche in exile better and has received considerable attention among the researchers. as a result Zenkovsky concluded that such children should be attached to the spiritual life, religious education, which will be a special factor in the spiritual formation of personality ..

Drawing an analogy with the events taking place in Ukraine, many children are forced to leave their usual places, school, friends, a lot of children have seen the devastation and death together, it can be argued that such views on education are still relevant.

Conclusions. The need of solving the problems in education largely depends on the need to rethink our own and the world's spiritual traditions of the past. The inclusion of national traditions to the modern global educational process can help to solve many problems of education and culture in general. However, we must develop forms and methods of educational potential philosophical and pedagogical ideas of the past to the present. Obviously, these methods must meet the requirements of time and be relevant to the specifics of today's education and should be covered by the objectives of today's society for the development of the welfare state.

\section{References}

1. Ukaz Prezydenta vid 17. 04. 2002 № 347/2002 "Pro natsionalnu doktrynu rozvytku osvity" [Edict of the president of Ukraine "About the national doctrine of education" from April 172002, № 347/2002]. Retrieved from http://zakon3.rada.gov.ua/laws/show/347/2002 [in Ukrainian].

2. Andrushchenko, V. P. (2005). Rozdumy pro osvitu [Reflections on education]. Kyiv: Znannia Ukrainy [in Ukrainian].

3. Zenkovskyy, V. V. (1926). Avtonomiia i teonomiia [Autonomy and theonomy]. Put - Path, 3, 46-64 [in Russian].

4. Zenkovskyy, V.V. (1927). Svoboda i sobornost [Freedom and Unification]. Put - Path, 7, 3-22 [in Russian].

5. Zenkovskyy, V. Prerequisites for the construction of a new school [The background in the construction of new school]. Russian school abroad - Russian school abroad, 2-3, 216-230 [in Ukrainian].

6. Zenkovskyy, V. V (1993). Problemy vospitaniia v svete khristianskoi antropologii [Problems of education in christian anthropology]. Moscow: St. Vladymyr brotherhood [in Russian]

7. Zenkovskyy, V. (2008). Dar svobody [Gift of freedom]. Sobranie sochinenii - Collected works (Vols. 2). Moscow, Russkii put [in Russian].

8. Zenkovskyy, V. (1997). Printsipy pravoslavnoi antropologii [Principles of the Orthodox anthropology]. Russkaia religioznaia antropologiia - Russian Religious anthropology. (Vols. 2), (pp. 431-466). Moscow [in Russian]. 
9. Zenkovsky, V. (1918). Sotsialnoe vospitanie ego zadachi i puti [Social education, its tasks and ways]. Moscow: Mosk. prosvet komis [in Russian].

10. Zenkovskyy, V. (1925). Deti emigratsii. Detskaia dusha v nashi dni [The children of emigration. Child's soul in Our Days]. Prague [in Russian].

11. Zenkovsky, V. (1929). O natsionalnom vospitanii [On national education]. Biulleten Religiozno-pedagogicheskogo kabineta - Bulletin of Religious-pedagogical office, 8, 1-2 [in Russian].

\section{Література}

1. Про національну доктрину розвитку освіти: Указ Президента від 17. 04. 2002. №347/2002. [Електронний ресурс] - Режим доступу http://zakon3.rada.gov.ua/laws/show/347/2002.

2. Андрущенко, В. П. Роздуми про освіту: Статті, нариси, інтерв'ю / В. П. Андрущенко. - К. : Знання України, 2005. $804 \mathrm{c}$.

3. Зеньковский, В. В. Автономия и теономия. / В. В. Зеньковский // Журнал «Путь». - 1927. - № 3. - С. 50

4. Зеньковский, В. В. Свобода и соборность / В. В. Зеньковский // Журнал «Путь». - 1927 - № 7. - С. 5.

5. Зеньковский, В. Предпосылки в строительстве новой школы / В. В. Зеньковский // Русская школа за рубежом. № 2-3. - С. 216-230.

6. Зеньковский, В. В. Проблемы воспитания в свете христианской антропологии / В. В.Зеньковский. - М. : СвятоВладимирское братство, 1993.

7. Зеньковский, В. В. Дар свободы / В. В. Зеньковский. - Париж, 1928.

8. Зеньковский, В. В. Принципы православной антропологии / В. В. Зеньковский // Русская религиозная антропология. Т. 2. - М., $1997-$ С. 431-466.

9. Зеньковский В. В. Социальное воспитание, его задачи и пути / В. В. Зеньковский. - М. : Моск. просвет. комиссия, 1918. $91 \mathrm{c}$.

10. Зеньковский, В. Дети эмиграции. Детская душа в наши дни. / В. В. Зеньковский. - Прага, 1925. - 251 с.

11. Зеньковский, В. О национальном воспитании / В. В. Зеньковский // Бюллетень Религиозно-педагогического кабинета. - 1929. - № 8. - С. 1-2

Received for publication 15.02.2017

\section{Бібліографічний опис для цитування :}

Zakharina, M. I. The education of free individual as the main value of the welfare of the social state in the scientific heritage of V. Zenkovsky / М. I. Zakharina // Проблеми соціальної роботи: філософфія, психологія, соціологія. - 2017. - № 1 (9). - С. 34-39. 